\title{
Building Façade Retrofit with Solar Passive Technologies: A Literature Review
}

\author{
Sara Brito-Coimbra ${ }^{1}(\mathbb{D})$, Daniel Aelenei ${ }^{1,2, *(\mathbb{D})}$, Maria Gloria Gomes ${ }^{3}(\mathbb{D})$ and Antonio Moret Rodrigues ${ }^{3}$ \\ 1 NOVA School of Science and Technology, NOVA University of Lisbon, 2829-516 Caparica, Portugal; \\ sara.brito.coimbra@gmail.com \\ 2 Centre of Technology and Systems/UNINOVA, FCT Campus, 2829-516 Caparica, Portugal \\ 3 CERIS, Department of Civil Engineering, Architecture and Georresources (DECivil), Instituto Superior \\ Técnico, Universidade de Lisboa, Av. Rovisco Pais, 1049-001 Lisbon, Portugal; \\ maria.gloria.gomes@tecnico.ulisboa.pt (M.G.G.); moret.rodrigues@tecnico.ulisboa.pt (A.M.R.) \\ * Correspondence: aelenei@fct.unl.pt
}

Citation: Brito-Coimbra, S.; Aelenei,

D.; Gloria Gomes, M.; Moret

Rodrigues, A. Building Façade Retrofit with Solar Passive

Technologies: A Literature Review.

Energies 2021, 14, 1774. https://

doi.org/10.3390/en14061774

Academic Editor: Chi-Ming Lai

Received: 28 February 2021

Accepted: 19 March 2021

Published: 23 March 2021

Publisher's Note: MDPI stays neutral with regard to jurisdictional claims in published maps and institutional affiliations.

Copyright: (c) 2021 by the authors. Licensee MDPI, Basel, Switzerland. This article is an open access article distributed under the terms and conditions of the Creative Commons Attribution (CC BY) license (https:/ / creativecommons.org/licenses/by/ $4.0 /)$.

\begin{abstract}
Worldwide, buildings have been presented as one of the main energy consumers and, for that matter, there is an increased tendency to invest in policies and measures that promote more efficient buildings. Among the chosen strategies, the need to promote the use of passive solutions and retrofit the existing building stock is often pointed out. Portuguese building stock has proven to be obsolete in terms of thermal comfort, which can directly affect the energy demand for climatization purposes. Considering the great solar availability in the country, when compared to other European locations, building retrofit with solar passive technologies can be a suitable solution. This paper aims to review studies on the application of solar passive technologies to retrofit façades in the Mediterranean climate context, with a special focus on Portugal. Four retrofit passive solar technologies were reviewed, namely glazing, sun shading, sunspaces and Trombe wall technologies.
\end{abstract}

Keywords: solar passive technologies; building retrofit; façade; Mediterranean climate

\section{Introduction}

Worldwide, buildings are presented as one of the main energy consumers [1]. Poor design of existing buildings, along with the improvement of living over the years, has contributed to a significant increase in energy consumption for space conditioning [2]. Consequently, several policies and regulations have been designed to promote more efficient buildings. The Energy Performance of Buildings Directive, also known as EPBD, is an example of policies [3-5]. It targets not only new but also existing buildings as the European building stock is mostly represented by the existing buildings.

To counter the aging of the existing European building stock, the best solution is to building retrofit [6], which can be seen as an opportunity to reduce energy consumption and improve the thermal comfort and well-being of the occupants [7]. Regarding the Portuguese context, according to the last Census [8], nearly $70 \%$ of the residential building stock was built prior to 1990, when the first thermal regulation was set up [9]. As a result, due to insufficient thermal insulation at the opaque building envelope, inappropriate windows (single-glazed windows with timber or aluminum without a thermal break frame) and lack of care with the regard to correction of thermal bridges, most of the buildings are in poor condition regarding thermal performance and energy efficiency. The last Portuguese Census [8] also showed that most of the needs to repair occur at the envelope level (walls, window frames and roof), which can directly impact the buildings' thermal performance. Indeed, buildings built prior to 1990 are responsible for higher energy demands for heating, ranging from 265 to $334 \mathrm{kWh} / \mathrm{m}^{2}$.year, while those built between 1990 and 2010 require between 112 and $265 \mathrm{kWh} / \mathrm{m}^{2}$.year [10]. According to a study performed in 2014 [11], approximately $80 \%$ of residential buildings had energy demands for heating higher than 
$100 \mathrm{kWh} / \mathrm{m}^{2}$.year, which is somehow concerning when analyzed in the context of oftenreferred "mild climates." Other studies have also shown that other Southern European countries with Mediterranean climates present similar needs to building retrofit to keep up with current building standards [12-17]. As stated by the updated World Map of the Köppen-Geiger climate classification [18], Mediterranean climates are characterized by cool and wet winters. Additionally, they are divided into two climate zones based on their summer characteristics: Csa (hot and dry summer) and Csb (warm and dry summer). Regarding mainland Portugal, the south is classified as Csa, while the north and center are classified as Csb.

Following the EPBD recast [4], Portuguese legislation [19] demands that the retrofit of the existing building stock should be progressively done toward implementing the concept of nearly zero-energy buildings (nZEB). These are buildings with very high energy performance due to passive strategies and renewable technologies, where the very low amount of energy that is required for their functioning is mainly covered by energy from renewable sources [4]. Generally, the strategy followed in implementing nZEB is divided into three different categories: Passive Strategies (e.g., Passive Solar Heat Gain), Energy Efficiency (e.g., Radiant Heating) and Renewable Energy Systems (e.g., Solar Thermal) [20].

Passive Strategies are normally the starting point for building designers as they can be applied to both residential and nonresidential buildings [20]. They are characterized by the direct interaction between the building envelope and the environment, and they address the heating, cooling and lighting needs of a building with the intent to prevent, reject/collect or control heat gains and/or natural lighting, without the use of electrical or mechanical equipment [19-21]. Among the Passive Strategies, solar passive technologies can be set as a viable solution to building retrofit under Mediterranean climates, as this climate is mostly known for its solar availability (solar hours and solar irradiance).

The literature on solar passive technologies is already very widespread. Some papers focused on the design optimization of passive solar strategies [21], while others focus on multiple technologies [22-25] or targeted a specific technology, such as Glazing [26], Sun Shading [27,28] and Trombe walls [29,30]. However, the literature review showed that there is an apparent lack of review papers on the application of solar passive technologies for building retrofit, especially in the Portuguese context. For this reason, the aim of this paper is to provide a literature review on the application of solar passive technologies to retrofit the façades of Portuguese buildings, considering the Mediterranean climate.

This paper is organized into four sections. The first section presents the motivation and the goal of the research. The second section briefly discussed solar availability in the Portuguese context and compared it to other European contexts. The third section describes the findings on studies about the application of solar passive technologies to retrofit Portuguese façades. Section four provides a brief discussion on the feasibility of retrofit actions with solar passive technologies. Finally, the fifth section draws conclusions from the previous sections.

\section{Solar Availability}

The potential of solar passive systems mainly relies on the availability of solar radiation, which is determined by the climate and latitude of the location and by the placement and position of the system [31,32]. Solar availability on urban façades is also impacted by the obstruction caused by nearby buildings [32].

Studies reported in the reviewed literature characterize solar availability either using the global vertical irradiation on the south façade or the global horizontal irradiation [33], [34]. In the Portuguese context, a study based on solar irradiation data devised by Brito et al. [35] analyzed the solar potential of roofs and façades of two different neighbors in Lisbon. According to their study, the annual solar irradiation of roofs varied between 1000 and $1800 \mathrm{kWh} / \mathrm{m}^{2}$.year, while façades varied between 100 and $1000 \mathrm{kWh} / \mathrm{m}^{2}$.year, depending on the façade orientation. The study also showed that façades facing east and 
west present a wide range of irradiation values $\left(100-800 \mathrm{kWh} / \mathrm{m}^{2} /\right.$ year), and the sum of their potential could surpass those facing south.

In this study, the annual Global Solar Irradiation (GSI) is used as an indicator to evaluate solar availability. Figure 1 shows the GSI of Lisbon when compared to other European locations, namely Ancona (Italy), Barcelona (Spain), London (United Kingdom), München (Germany), Paris (France) and Stockholm (Sweden). The data correspond to 2015 and were obtained from the Photovoltaic Geographical Information System of the EU Science Hub of the European Commission [36]. As can be seen in Figure 1, high annual values were recorded in all locations of Mediterranean climates (Lisbon, Ancona and Barcelona), the highest value being associated with Lisbon $\left(1789 \mathrm{kWh} / \mathrm{m}^{2}\right.$.year). When compared to Paris, Munich, London and Stockholm, Lisbon's GSI is 31\%, 33\%, 41\% and $48 \%$ higher than the corresponding values, respectively.

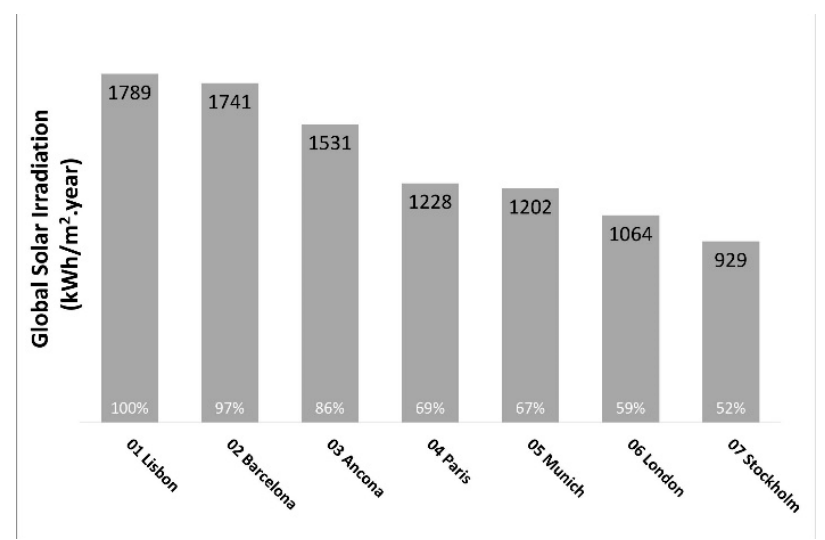

Figure 1. Annual sum of Global Solar Irradiation (GSI) in 2015.

\section{Solar Passive Technologies}

In this section, the key findings of the studies devised on the application of solar passive technologies used to retrofit façades of Portuguese buildings, considering the Mediterranean climate, are presented.

As Passive Strategies, solar technologies can address both, heating and cooling needs by preventing, rejecting/collecting, or controlling heat gains. Solar technologies can be categorized as Direct and Indirect Solar Gain Technologies [37]. Direct Gain Solar Technologies absorb, store and release solar energy directly into the indoor environment (Figure 2a) [38].

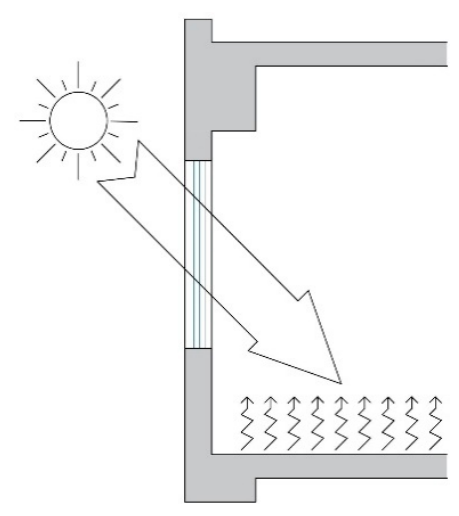

(a)

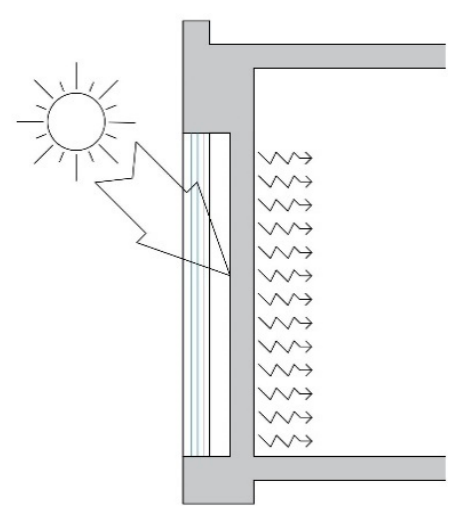

(b)

Figure 2. Examples of solar passive technologies: (a) direct solar gain through a window; (b) indirect solar gain through a Trombe wall system. 
In the case of indirect solar gain technologies, solar energy is first absorbed by a thermal mass and then transferred into the indoor environment for later use (Figure 2b) [37]. A matrix of suitable retrofit solutions for each case is presented in Table 1, and the retrofit solutions are described in detail in Sections 3.1-3.4.

Table 1. Solar technologies used to retrofit according to the type of solar gain and target season.

\begin{tabular}{cccc}
\hline \multirow{2}{*}{ Type of Solar Gain } & Solar Technology & Targets \\
\cline { 3 - 4 } & & Heating Season & Cooling Season \\
\hline \multirow{2}{*}{ Direct } & $\begin{array}{c}\text { Glazing technologies } \\
\text { Sun shading technologies }\end{array}$ & $\sqrt{ }$ & $\sqrt{ }$ \\
\hline \multirow{2}{*}{ Indirect } & Sunspace technologies & $\sqrt{ }$ & \\
& Trombe wall technologies & $\sqrt{ }$ & \\
\hline
\end{tabular}

At the end of the section, a table is given that summarizes the main findings from the literature review (Table 2).

\subsection{Glazing Technologies}

Worldwide, window retrofit is, without any doubt, the most popular retrofit action. The reasons behind this success are threefold. Firstly, windows usually present higher thermal transmittance values ( $U$-values) than the opaque façade [26], and, as consequence, most of the heat exchange between the exterior and interior environment occurs via glazed spans [39]. Secondly, financial support programs often encourage window retrofit. In the Portuguese context, the "Renew Home \& Office" program [40] is an example of such programs. Thirdly, windows are the simplest solar passive technology and the easiest building element to retrofit [20,37].

In the Portuguese context, window retrofit is either done by:

- Installing a secondary window in addition to the existing single-glazed window;

- Replacing the entire window system;

- Adding Solar Control Films (SCFs) to the existing window.

Window retrofit through the installation of a secondary window is based on the internal addition of a second pane of glass or plastic, while keeping the original single-glazed window, to improve the thermal performance of the window system during wintertime [40]. This solution can also maintain the external original aesthetics of the renovated window system, which is useful in the case of retrofitting the historical buildings, as shown in Figure 3, which illustrates the impact of the retrofitting on a building located in the UNESCO's Historic Centre of Porto [41]. No measurable impact of this type of retrofit solution was found in the literature for the Portuguese context.

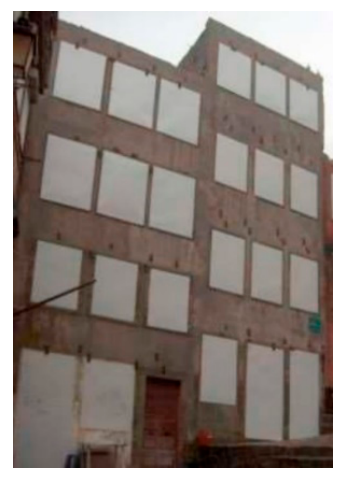

(a)

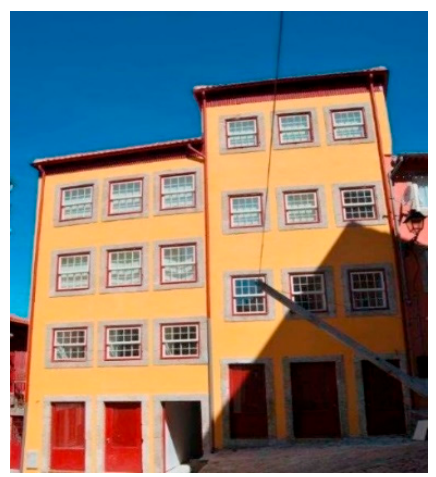

(b)

Figure 3. Example showing the impact of window retrofitting on a building located in the Historic Centre of Porto (a) before and (b) after the intervention [41]. 
Regarding the replacement of window systems, most Portuguese studies considered the replacement of single glazing with multilayer glazings. On the whole, triple-glazed windows were usually chosen for locations in the north and center-north of the mainland, as shown in [42]. However, the replacement with double-glazed windows was the most common solution nationwide for both residential and nonresidential buildings, as shown in [41,43-49] and [50,51], respectively. It is estimated that replacing single- with doubleglazed windows is an investment that can cost between 200 and $1500 \mathrm{EUR} /$ unit, whereas the investment in retrofit measures of the opaque walls with traditional External Thermal Insulation Composite Systems (ETICSs) is between 30 and $60 \mathrm{EUR} / \mathrm{m}^{2}$. The measurable impact of replacing single- with double-glazed windows was studied by Eskander et al. [47], who verified that the heat transferred through the windows could be lowered to near $40 \%$ following the retrofit. Eicker et al. [52] analyzed the impact of replacing glazing systems with ones with lower total solar energy transmittance ( $g$-value), a parameter that is also known as the solar factor. According to [53], the $g$-value represents the quotient between the energy transmitted to the interior through a glazed gap and the energy of the solar radiation that affects it. The researchers concluded that the cooling energy needs of a residential building in Almada (a city and a municipality in Portugal located on the southern margin of the Tagus River from Lisbon) could be lowered to $11 \%$ if single-glazed windows with a $g$-value of 0.8 were replaced with double-glazed windows with a $g$-value of 0.51 [52].

Other studies considered the replacement of single-glazed windows with doubleglazed and low-emissive (e-low) glazing windows [42,54]. The literature pointed out that e-low glazing is a good option for a mild-temperate climate (Portugal mainland) because it provides good thermal insulation during wintertime and reduces the entrance of heat during summertime, allowing the passage of visible light for daylight $[38,55]$.

As stated by Moretti and Belloni [56], to encourage visual comfort and daylighting for energy savings, nonresidential buildings tend to have high window-to-wall ratios. However, this design option may also lead to an increase in energy demand for heating or cooling purposes. For that reason, in recent years, many studies have been devised on glazing retrofit with Solar Control Films (SCFs) [57-59]. In Portugal, Teixeira et al. [59] studied an office building with large glazed areas in Lisbon and concluded that SCFs can be a suitable retrofit measure as they can reduce solar heat gains, the peak demand load and the annual energy consumption. These findings are pertinent because, as Causone et al. [60] pointed out, large glazed surfaces can cause a significant increase of cooling loads in warm climates due to the increased solar heat gain. Furthermore, Pereira et al. [57] also studied the application of SCF in the Lisbon context and verified that this retrofit solution has the potential to promote daylight availability while limiting the visual discomfort in office buildings (Figure 4).

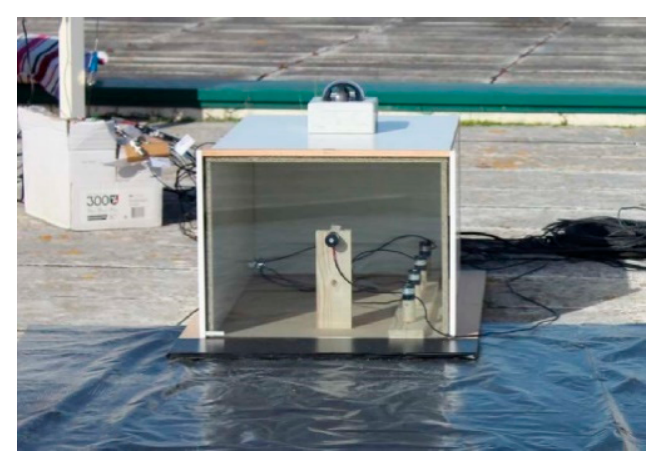

(a)

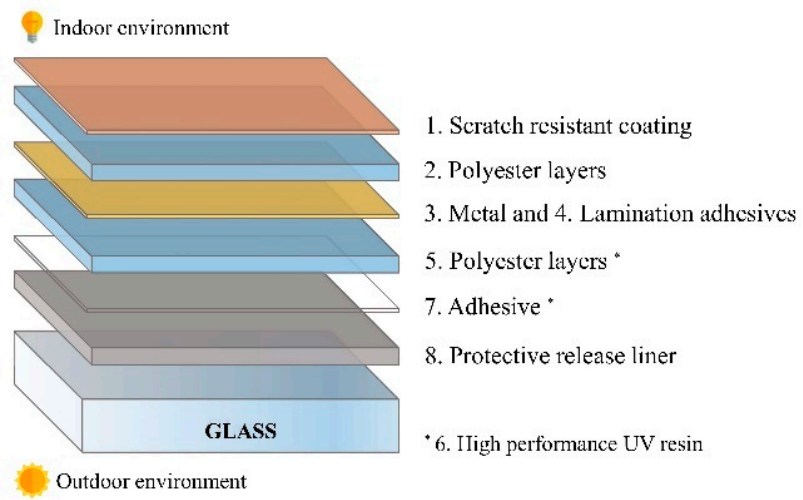

(b)

Figure 4. Glazing retrofit with Solar Control Films: (a) small-scale model (1:10); (b) standard structure with an internal application on the glass surface [57]. 


\subsection{Sun Shading Technologies}

Portuguese cities such as Évora and Beja are characterized by very hot summers, with average temperatures of $30.2 \mathrm{C}$ and $32.6{ }^{\circ} \mathrm{C}$, respectively, while Lisbon has an average maximum temperature of $27.4^{\circ} \mathrm{C}$ in July [61,62]. Thermal discomfort due to overheating, during the cooling season, is often pointed as a key issue, as shown in [63]. For this reason, the control of solar heating gains is a key retrofit measure in the Portuguese context [64]. The most effective way to control solar heat gain is by intercepting it before it reaches the building envelope while ensuring that the strategy does not interfere with solar gains during wintertime when it is required [65]. This control can be achieved using sun shading devices, as shown in $[66,67]$. This solar technology is often considered and recommended in building retrofit studies, as shown in $[42,68,69]$.

Capeluto et al. [70] analyzed the retrofit of façades in multiple European cities and concluded that, when a single strategy was chosen to retrofit a south-facing façade in Porto, sun shading was the best option. The study also showed that, even when multiple strategies are chosen, sun shading appears twice in the top three combined measures, first combined with glazing and in third combined with ventilation.

Studies on the individual impact of sun shading retrofitting in the Portuguese context are scarce. It appears from the literature that, with very few exceptions, this retrofit option was always considered in conjunction with other retrofit measures. In other words, the specific measurable impact of sun shading retrofit was rarely presented and discussed. One of the exceptions was presented by Pereira Tavares et al. [38], who assessed the impact of adding horizontal brise-soleils of different sizes to housing units in Lisbon (Figure 5). The authors concluded that by adding horizontal brise-soleils to buildings with large glazing areas, the cooling energy needs could be lowered by up to $55 \%$, depending on the façade orientation and the type of glass of the window. The study also showed that the greater the width of the used shading devices, the lower the influence of the type of glass of the window.
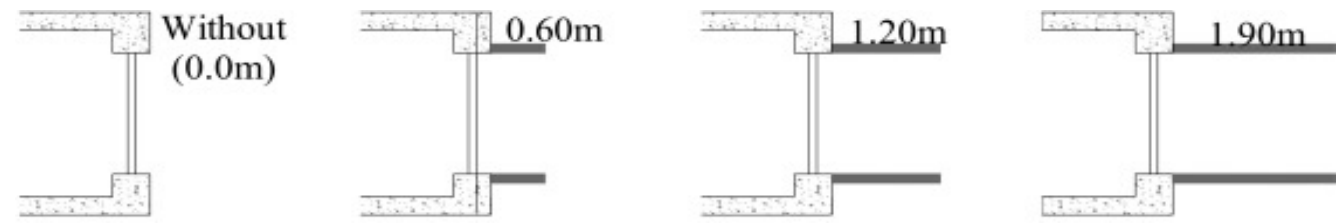

Figure 5. Sun shading retrofit with horizontal brise-soleils with different sizes [38].

Another exception was presented by Palmero-Marrero et al. [71], who analyzed the effect of louver shading devices on building energy requirements of multiple cities across the world, including Lisbon. The authors showed that $50 \%$ of the total energy consumption could be saved by using louvers (Figure 6), compared with no shading case. Nevertheless, both studies pointed that adding shading devices can lead to higher energy expenditure during the heating season.

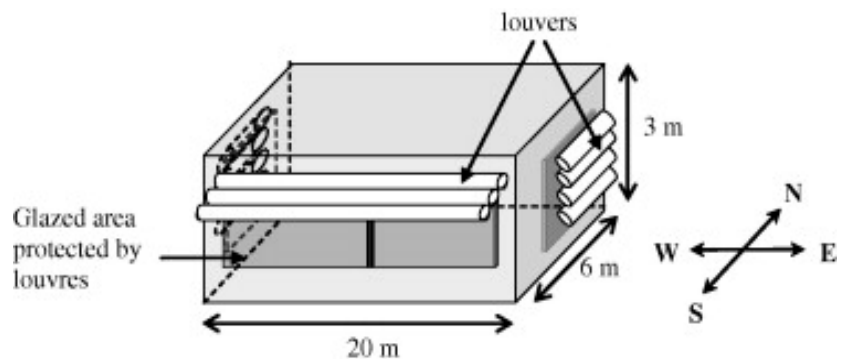

Figure 6. Sun shading retrofit with louvers (horizontal layout in a south façade and vertical layout in east or west façades) [71]. 
Regarding the design of sun shading, the literature emphasized several aspects. The adaptability should be weighed, namely if the shading device is fixed or movable. The aesthetics and handling of shading devices should also be taken into account because they are often pointed as key factors for users [72,73]. As shading devices can reduce natural light, designers should assess the balance between the energy savings from cooling (due to shading devices) and the energy consumption due to artificial light.

\subsection{Sunspace Technologies}

Sunspace is a solar technology designed to collect heat gains. It is based on a glasshouse (Figure 7) that absorbs solar radiation and partially converts it into energy for heating the indoor environment [74-77].

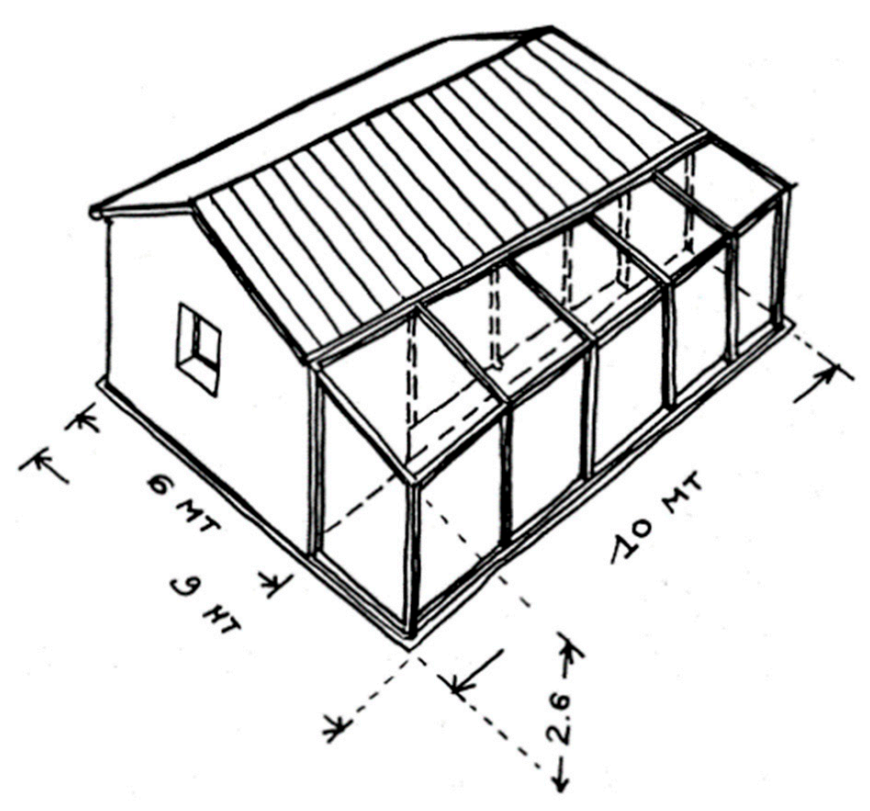

Figure 7. Illustration of a sunspace [77].

It recreates on a small scale the macroscopic phenomenon of the greenhouse effect that happens between the Earth and the atmosphere, and it works as a buffer zone against heat losses toward the outdoor environment $[74,75]$. Portuguese sunspaces are usually south oriented, with single glazing and a high glazing to floor surface ratio (between $60 \%$ and $250 \%$ ) [78].

Case studies on Portuguese retrofitted sunspaces are scarce, even though it is common to close existing balconies so that they can perform as sunspaces. Such an example was studied by Macieira et al. [79], who proposed the use of transparent membrane screens to close existing balconies (Figure 8a). To optimize the thermal performance, the proposed retrofit solution can be completely open all day or night time, and it can also integrate an additional opaque/reflective membrane to work as a vertical shade (with adjustable height), as shown in Figure 8b. As the proposed retrofit solution uses membranes of PVC or EFTE as an alternative to conventional glazing, the technology was named Membrane Alternative Sunspace (MAS). The study concluded that MAS is an efficient alternative to traditional sunspaces, according to constructive, environmental and economic aspects. 


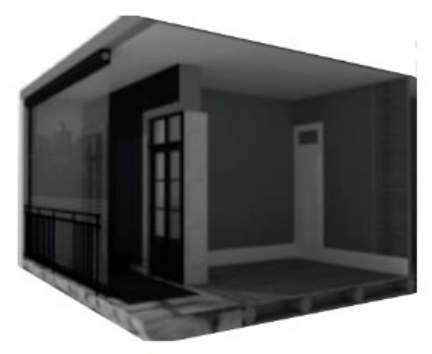

(a)

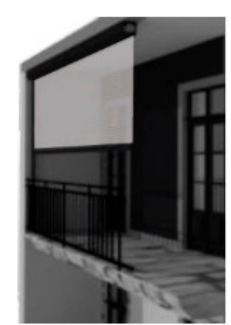

(b)

Figure 8. Retrofitted sunspace during the daytime period in the: (a) heating season; (b) cooling season with an open (adjustable) membrane [79].

Aelenei et al. [80] studied the use of different attached-sunspace configurations (Figure 9) in retrofitting design and concluded that fully integrated sunspaces led to betterperforming results because they have a smaller glazing area in contact with the external environment. The study also pointed that sunspaces may be a very efficient solution in the south of mainland Portugal (e.g., Faro region), as it evidenced a potential of 100\% energy saving during wintertime. However, in locations with more severe winters, such as Bragança, the potential energy savings is lowered to $48 \%$. Furthermore, sunspaces might be a very attractive solution to retrofit dwellings built before the 1990s when compared to retrofit approaches based on thermal insulation due to the good solar potential in Portugal and the economic benefits of sunspace systems [80].

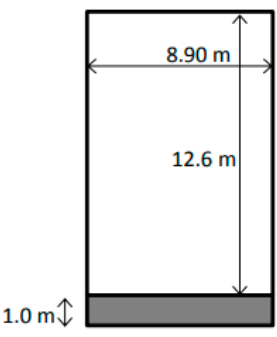

(a)

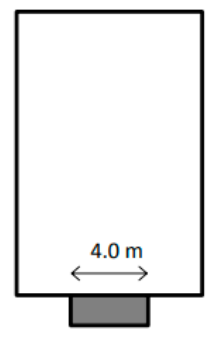

(b)

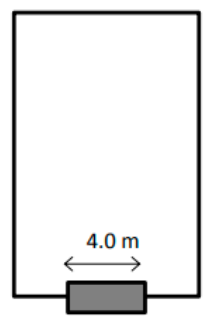

(c)

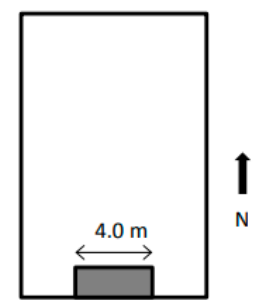

(d)

Figure 9. Types of sunspaces: (a) adjacent; (b) adjacent; (c) partially integrated; (d) totally integrated [80].

\subsection{Trombe Wall Technologies}

Trombe wall, also known as a storage wall or a solar heating wall, is a solar technology mainly designed to collect heat gains. It consists of an external transparent layer in front of the external wall (known as a massive wall), with a small air cavity between them. The system works by absorbing solar energy through the external transparent skin, which results in a buffer effect in the air cavity, where the heat is stored during the daytime [81-83]. In the hours following the sunset, the energy is transmitted as heat to the indoor environment, which enhances the indoor air temperature [81-83].

According to the ventilation mode of the air cavity of the Trombe wall system, it can be classified as nonventilated (or unvented), ventilated or double ventilated. The ventilation mode relies on the existence of vents (ventilation openings) on the external transparent skin or the massive wall. When the Trombe wall is designed without vents, or the vents are closed, the system is classified as unvented. If the Trombe wall has (open) vents in one layer of the system (e.g., external transparent skin or massive wall), it is classified as ventilated. When the Trombe wall has (open) vents in different two layers of the system, namely on the external transparent skin and on the massive wall, the system is classified 
as double ventilated. Each one of the described ventilation modes of the Trombe wall is illustrated in Figure 10.

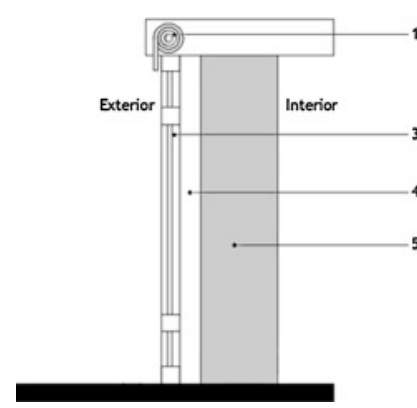

(a)

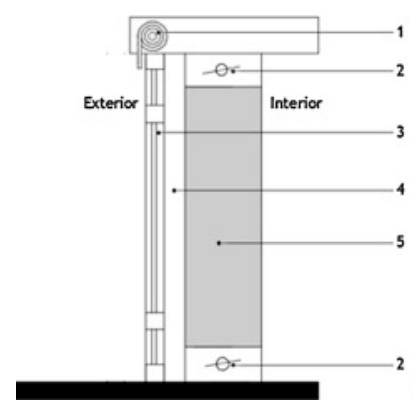

(b)

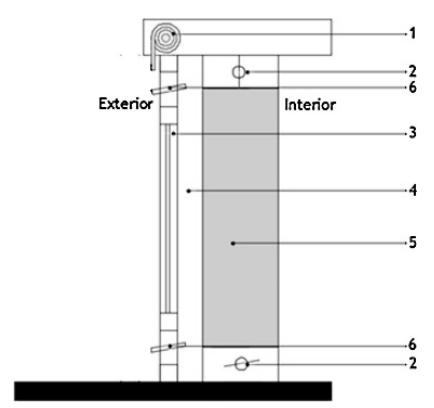

(c)

Figure 10. Configuration of different Trombe walls: (a) nonventilated or unvented; (b) classic or ventilated; (c) double ventilated: 1 -shading device; 2 -ventilation openings in the massive wall; 3-glazing; 4-air layer; 5-massive wall; 6-ventilation openings in the glazing [84].

Trombe wall technologies are not commonly used to retrofit residential buildings in Portugal, perhaps due to the lack of information among Portuguese building designers on the application and efficiency of this constructive solution [85]. Nevertheless, among solar technologies, a Trombe wall seems to be a suitable retrofit solution for residential buildings due to its simple configuration, zero running costs, among other reasons [86,87].

As Trombe wall systems are not commonly used in Portugal, studies on their application and impact are also scarce. The studies developed by Briga-Sá et al. $[84,85,88]$ are one of the few exceptions. With regard to the performance, the researchers concluded that the integration of a Trombe wall is beneficial for the performance of Portuguese buildings, given the fact that the energy needs for heating can be reduced up to approximately $16 \%$ [85]. Other key findings have also been presented in the literature with regard to the application of Trombe wall systems in European locations with Mediterranean climates. For example, the optimized design of a Trombe wall is often a double-glazed layer, as seen in [33,84,88-91], with air layer depths lower than $10 \mathrm{~cm}$, as seen in [88,89,92]. In addition, during summertime is strongly recommended the use of sun shading to counter overheating. This statement was referred to both in Portuguese studies $[84,90]$ and studies devised on other European regions with Mediterranean climates [89,93]. For example, Briga-Sá et al. [84] noticed that the outer surface of the Trombe wall can reach temperatures above $60^{\circ} \mathrm{C}$ when it is unscreened but under $30^{\circ} \mathrm{C}$ when it is shaded.

In recent years, the literature also presented some innovative Trombe wall technologies considering the Portuguese context. Sacht et al. [90] investigated the performance of a modular Trombe wall (Figure 11) for building retrofit under different Portuguese climates. The proposed retrofit solution is innovative for two reasons. Firstly, it is based on multiple modules of a Trombe wall, instead of a single zone, and modules are normally used in active system devices (e.g., PV modules). In addition, the study showed that, regardless of the location, when the modular Trombe wall was considered, the heating energy demand met the Portuguese building code requirements.

Another innovative technology within Trombe wall systems was presented in the literature by Aelenei et al. [94]. They proposed a complementary solution to a traditional External Thermal Insulation Composite System (ETICS), which targets thermal bridge areas with the intent to mitigate winter heat losses (Figure 12). The proposed solution relies on the principle of unvented Trombe walls, but it considers the external transparent skin in front of a structural thermal bridge area (boundary between concrete columns and masonry walls). The design of this innovative concept, named Solar Bridge Retrofit System (SBRS), enables heavy structures of the building (e.g., concrete columns) to absorb solar radiation and conduct the heat slowly inward or to the adjacent structure [94]. 


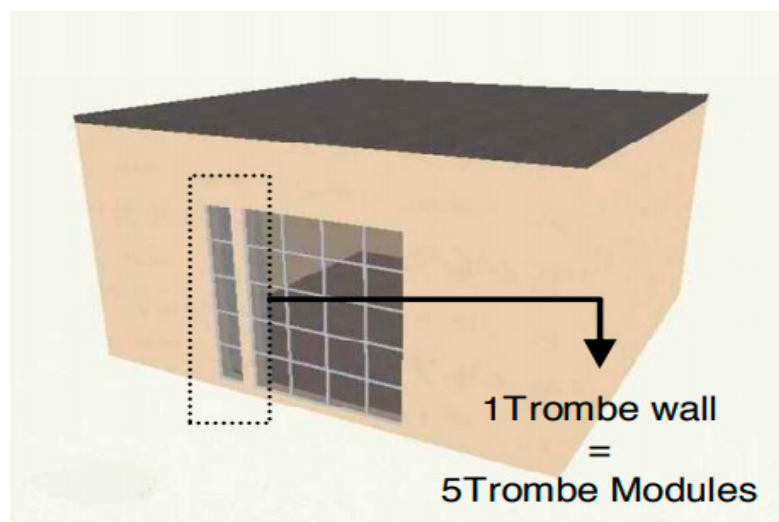

Figure 11. Trombe wall technology: modular Trombe wall. Reproduced with permission from [90].

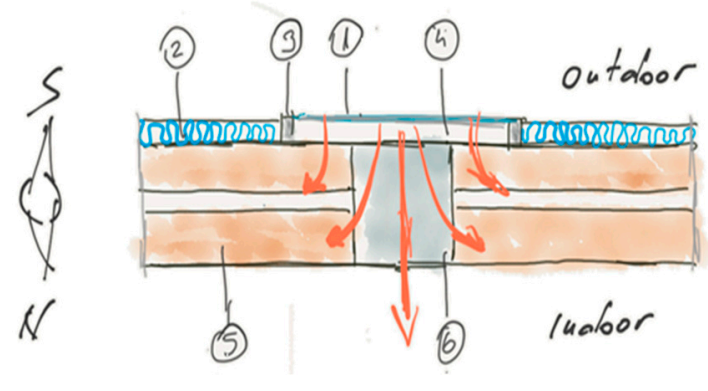

(a)

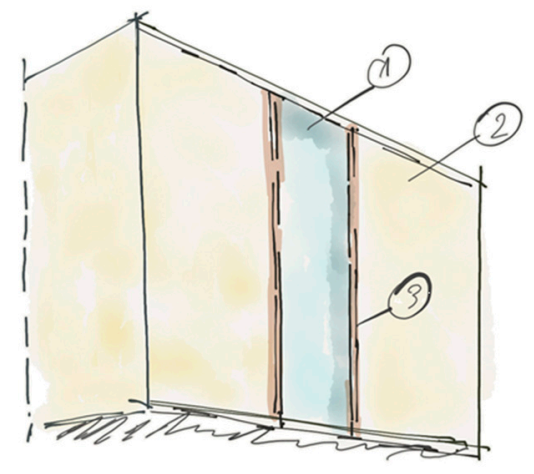

(b)

Figure 12. Conceptual drawing of the Solar Bridge Retrofit System (SBRS) designed to correct the thermal bridges introduced by concrete columns: (a) Horizontal cross-section; (b) 3D View (right-hand side): 1-external transparent skin (glazing); 2-External Thermal Insulation Composite System (ETICS); 3-frame of the glazing; 4-air cavity of the SBRS; 5-masonry wall; 6-concrete column [94].

Table 2 summarizes the main findings reported in the literature regarding the reviewed solar passive technologies. 
Table 2. Literature review matrix of the reviewed studies on solar technologies used to building retrofit Portuguese buildings.

\begin{tabular}{|c|c|c|c|c|c|c|c|c|c|}
\hline \multirow{3}{*}{$\begin{array}{l}\text { Solar Passive Technology } \\
\text { Glazing technologies }\end{array}$} & \multirow{2}{*}{$\begin{array}{l}\text { Location } \\
\text { Multiple locations, } \\
\text { including Portugal } \\
\text { (Almada) }\end{array}$} & \multirow{2}{*}{$\begin{array}{l}\text { Type of Study } \\
\text { Numerical }\end{array}$} & \multirow{2}{*}{$\begin{array}{l}\text { Type of Building } \\
\text { Residential }\end{array}$} & Energy Analysis & \multicolumn{2}{|c|}{$\begin{array}{l}\text { General Findings: } \\
\text { Benefits }\end{array}$} & \multicolumn{2}{|c|}{$\begin{array}{l}\text { General Findings: } \\
\text { Drawbacks and } \\
\text { Recommendations }\end{array}$} & \multirow{2}{*}{$\begin{array}{l}\text { Ref } \\
{[52]}\end{array}$} \\
\hline & & & & $\begin{array}{l}\text { Replacing single-glazed } \\
\text { windows with } \\
\text { double-glazed can lower } \\
\text { cooling energy } \\
\text { needs to } 11 \% \text {. }\end{array}$ & घ & N.A. & $\mathbf{\square}$ & N.A. & \\
\hline & Portugal (Lisbon) & $\begin{array}{l}\text { Experimental and } \\
\text { numerical }\end{array}$ & Office & $\begin{array}{l}\text { Retrofitting large glazing } \\
\text { areas with Solar Control } \\
\text { Films can reduce solar heat } \\
\text { gains, the peak demand } \\
\text { load and the annual } \\
\text { energy consumption. }\end{array}$ & घ & N.A. & घ & N.A. & [59] \\
\hline \multirow[t]{3}{*}{ Sun shading technologies } & Portugal (Lisbon) & Numerical & Residential & $\begin{array}{l}\text { Horizontal brise-soleils can } \\
\text { lower up to } 55 \% \text { of the } \\
\text { cooling energy needs, } \\
\text { depending on the façade } \\
\text { orientation and the type of } \\
\text { glass of the window. }\end{array}$ & - & N.A. & घ & $\begin{array}{l}\text { Applied shading devices } \\
\text { can lead to higher energy } \\
\text { expenditure during the } \\
\text { heating season. }\end{array}$ & {$[38]$} \\
\hline & $\begin{array}{l}\text { Multiple locations, } \\
\text { including Portugal (Porto) }\end{array}$ & Numerical & Residential & - N.A. & घ & $\begin{array}{l}\text { Regarding the retrofit of } \\
\text { a south face, sun shading } \\
\text { is the best single strategy } \\
\text { but also appears twice in } \\
\text { the top } 3 \text { combined } \\
\text { strategies (1st shading + } \\
\text { glazing; 3rd } \\
\text { ventilation + shading). }\end{array}$ & घ & N.A. & [70] \\
\hline & $\begin{array}{l}\text { Multiple locations, } \\
\text { including Portugal } \\
\text { (Lisbon) }\end{array}$ & Numerical & Residential & $\begin{array}{l}50 \% \text { of the total energy } \\
\text { consumption could be } \\
\text { saved by using louvers, } \\
\text { compared with no shading. }\end{array}$ & घ & N.A. & घ & $\begin{array}{l}\text { Louvers can increase } \\
\text { heating energy needs. }\end{array}$ & [71] \\
\hline Sunspace technologies & Portugal (Porto) & $\begin{array}{l}\text { Experimental and } \\
\text { numerical }\end{array}$ & Residential & - N.A. & - & $\begin{array}{l}\text { Retrofit sunspaces with } \\
\text { membranes (instead of } \\
\text { glazing) allow design } \\
\text { customization. } \\
\text { Compared to glass: (a) } \\
\text { easier and quicker } \\
\text { retrofit with membranes; } \\
\text { (b) easier to repair or } \\
\text { replace membranes } \\
\text { when damaged; (c) } \\
\text { provide protection } \\
\text { against material } \\
\text { projection in the case of a } \\
\text { seismic event). }\end{array}$ & - & $\begin{array}{l}\text { Not all intervention } \\
\text { scenarios can be } \\
\text { retrofitted with } \\
\text { membranes (although } \\
\text { membranes are } \\
\text { interesting alternatives } \\
\text { when the use of glass is } \\
\text { limited due to its size, } \\
\text { weight and/or cost). }\end{array}$ & [79] \\
\hline
\end{tabular}


Table 2. Cont

\begin{tabular}{|c|c|c|c|c|c|c|c|}
\hline \multirow[t]{2}{*}{ Solar Passive Technology } & \multirow{2}{*}{$\begin{array}{l}\text { Location } \\
\text { Portugal (multiple } \\
\text { locations on the mainland) }\end{array}$} & \multirow{2}{*}{\begin{tabular}{|l|} 
Type of Study \\
Numerical
\end{tabular}} & \multirow{2}{*}{$\begin{array}{l}\text { Type of Building } \\
\text { Residential }\end{array}$} & Energy Analysis & $\begin{array}{l}\text { General Findings: } \\
\text { Benefits }\end{array}$ & $\begin{array}{l}\text { General Findings: } \\
\text { Drawbacks and } \\
\text { Recommendations }\end{array}$ & \multirow{2}{*}{$\begin{array}{l}\text { Ref. } \\
{[80]}\end{array}$} \\
\hline & & & & $\begin{array}{l}\text { - Sunspaces are very efficient } \\
\text { solutions to south } \\
\text { Portuguese locations as } \\
\text { they can lead to } 100 \% \\
\text { energy saving during } \\
\text { wintertime. }\end{array}$ & $\begin{array}{l}\text { Totally integrated } \\
\text { sunspaces perform better } \\
\text { results than adjacent and } \\
\text { partially integrated } \\
\text { because they have a } \\
\text { smaller glazing area in } \\
\text { contact with the external } \\
\text { environment. }\end{array}$ & $\begin{array}{l}\text { Designing sunspaces } \\
\text { with opaque glazing can } \\
\text { be a good solution to } \\
\text { avoid overheating } \\
\text { during the cooling } \\
\text { season. }\end{array}$ & \\
\hline \multirow[t]{3}{*}{ Trombe wall } & Portugal (Vila Real) & $\begin{array}{l}\text { Experimental and } \\
\text { numerical }\end{array}$ & Test cell & $\begin{array}{l}\text { The integration of a vented } \\
\text { or an unvented Trombe } \\
\text { wall in the façade can } \\
\text { decrease the heating } \\
\text { energy needs up to nearly } \\
16 \% \text { and } 9 \% \text {, respectively. }\end{array}$ & $\begin{array}{l}\text { The heat takes near } 3 \\
\text { times more to reach the } \\
\text { indoor environment if } \\
\text { there is no ventilation in } \\
\text { the massive wall. }\end{array}$ & $\begin{array}{l}\text { Cooling season: shading } \\
\text { devices are strongly } \\
\text { recommended because } \\
\text { the outer surface of the } \\
\text { Trombe wall can exceed } \\
60^{\circ} \mathrm{C} \text { when unshaded. If } \\
\text { shaded, the values are } \\
\text { reduced to } 30^{\circ} \mathrm{C} \text { or less. } \\
\text { During the cooling } \\
\text { season, it may be } \\
\text { necessary to combine a } \\
\text { Trombe wall with night } \\
\text { ventilation and/or } \\
\text { shading devices to } \\
\text { improve the overall } \\
\text { performance. }\end{array}$ & {$[84,85,88]$} \\
\hline & Portugal (Caparica) & Experimental & Test cell & - N.A. & $\begin{array}{l}\text { Trombe wall systems } \\
\text { applied to structural } \\
\text { thermal bridge areas can } \\
\text { help promote heat gain } \\
\text { (instead of heat losses } \\
\text { due to the thermal } \\
\text { bridge phenomenon). }\end{array}$ & - N.A. & [94] \\
\hline & $\begin{array}{l}\text { Portugal (Lisbon, Porto, } \\
\text { Lajes, Funchal) }\end{array}$ & Numerical & Test cell & $\begin{array}{l}\text { Trombe wall modules } \\
\text { lower the heating energy } \\
\text { needs. } \\
\text { Trombe wall in the south } \\
\text { façade led to lower heating } \\
\text { than in east, west and } \\
\text { north façades, regardless of } \\
\text { the geographic location. }\end{array}$ & - N.A. & $\begin{array}{l}\text { It is also very important } \\
\text { to consider the cooling } \\
\text { energy needs when } \\
\text { considering Trombe } \\
\text { wall systems. }\end{array}$ & [90] \\
\hline
\end{tabular}




\section{Feasibility of Retrofit Works with Solar Passive Technologies}

Each building is unique and, thus, it is the nature of its retrofit project, which makes it difficult to define general action guidelines and implies that the optimal solution should be defined for each retrofit case [6]. To facilitate the process of finding the optimal retrofit solutions for each case, the literature presented assessment methodologies on the feasibility of the retrofit works. Those methodologies, such as those presented in $[95,96]$, were designed to assess any kind of retrofit works and not specifically the retrofit works with solar passive technologies. Nevertheless, the performance indicators associated with those methodologies may be used to assess the feasibility of the solar passive technologies listed in Section 3 as well.

Table 3 presents a list of indicators that can help assess the feasibility of retrofit projects with solar passive technologies.

Table 3. Performance indicators that can be used to assess the feasibility of retrofit projects with solar passive technologies.

\begin{tabular}{|c|c|c|}
\hline Scope & Indicator & Unit \\
\hline Solar availability & $\begin{array}{c}\text { Solar irradiation on the façade surface } \\
\text { Hours of solar exposure }\end{array}$ & $\begin{array}{l}\mathrm{kWh} / \mathrm{m}^{2} / \text { year } \\
\text { Hours }\end{array}$ \\
\hline Thermal performance and comfort & $\begin{array}{c}\text { Discomfort period } \\
\text { Heat gain } \\
\text { Heat transmission (Heat flux) } \\
\text { Predicted Mean Vote (PMV) } \\
\text { Relative humidity } \\
\text { Temperature (surface: glazing and massive wall; cavity) } \\
\text { Time lag }\end{array}$ & $\begin{array}{c}\text { Hours; } \% \\
\mathrm{MJ} / \mathrm{m}^{2} ; \mathrm{kW} / \mathrm{m}^{2} \\
\mathrm{~W} / \mathrm{m}^{2} \\
- \\
\% \\
{ }^{\circ} \mathrm{C} \\
\text { Hours }\end{array}$ \\
\hline Indoor air quality and acoustics & $\begin{array}{l}\mathrm{CO}_{2} \text { concentration } \\
\text { Acoustics }\end{array}$ & $\begin{array}{c}\text { ppm } \\
-\mathrm{dB} ; \mathrm{RT} 60\end{array}$ \\
\hline Energy efficiency & $\begin{array}{l}\text { Cooling energy needs (or cooling energy needs savings) } \\
\text { Energy storage (and release) } \\
\text { Heating energy needs (or heating energy needs savings) }\end{array}$ & $\begin{array}{l}\text { kWh; kWh/year; \% } \\
\text { Hours } \\
\text { kWh; kWh/year; \% }\end{array}$ \\
\hline Environment & $\begin{array}{l}\mathrm{CO}_{2} \text { emissions (production and operational phase) } \\
\text { Energy demand (production and operational phase) }\end{array}$ & $\begin{array}{c}\mathrm{kg} \mathrm{CO} 2 \text { eq. } \\
\mathrm{kWh} ; \mathrm{kWh} / \mathrm{m}^{2}\end{array}$ \\
\hline Economic & $\begin{array}{c}\text { Annual savings } \\
\text { Internal rate of return (IRR) } \\
\text { Investment costs } \\
\text { Net present value (NPV) } \\
\text { Payback period (PP) } \\
\text { Savings-to-investment ratio (SIR) }\end{array}$ & $\begin{array}{l}€ ; \% \\
- \\
€ \\
- \\
\text { Years } \\
-\end{array}$ \\
\hline
\end{tabular}

It should be noted that retrofit measures usually lead to lower energy needs, but that does not always imply a lower global cost [95]. Therefore, studies on the feasibility should not only be based on energy efficiency indicators but also thermal performance and comfort, indoor air quality and acoustics, fire protection and environment and economic indicators. Furthermore, retrofit design projects should also include consideration of the following aspects:

- Retrofit conditions-questions such as the disturbance levels to the inhabitants or site and the possibility of working from the inside of the building vs. the need for scaffoldings in high-rise buildings should be holistically weighed, as shown in [97].

- Compatibility between the existing constructive solutions and the proposing retrofit technologies - the retrofit design project should be compatible with the existing solution (e.g., materials properties), and possible consequences should be assessed (e.g., reduction of air permeability and the creation of new thermal bridge areas following the fixation of new constructive systems), as well as how to mitigate them [98]; 
- Impact on cultural heritage-the retrofit design project should involve a strong dichotomy between aesthetic-architectonical value and energy efficiency goals, especially in the context of the rehabilitation of historic buildings [99].

\section{Conclusions}

This paper presents an overview of the state-of-art solar passive technologies used to retrofit Portuguese façades. The final remarks and recommendations for future works are presented as follows:

1. Direct solar technologies (glazing and sun shading) are commonly used strategies to thermally retrofit Portuguese façades, and they are often applied together. Their widespread application is assisted by: (a) their simplicity (easy elements to retrofit); (b) the Portuguese regulation that presents design parameters (which facilitates the job of building designers); (c) national financial support programs (incentives). Sun shading is often recommended in the literature, but its specific impact is usually not indicated.

2. There is an apparent scarcity of studies on indirect solar technologies used to retrofit Portuguese buildings. Regarding sunspaces, even though balconies are often converted into sunspaces, there are no sufficient available data on the optimization design parameters leading to the upgrade of the energy performance. Regarding Trombe wall systems, most of the studies found were devised in the last decade, meaning that there is a growing interest in this subject. All in all, more detailed studies and research (on optimization design, operation, and efficiency) should be devised on Trombe wall systems to encourage building designers and owners to consider this technology.

3. Studies have shown that solar passive technologies usually lead to energy savings. However, more detailed feasibility studies should be conducted, especially concerning cost and environmental indicators. Specific studies on the feasibility of solar passive technologies compared to conventional retrofit solutions should also be conducted to further increase the knowledge on solar passive technologies in the Portuguese context.

4. Overall, it was concluded that building retrofit with solar passive technologies may be a viable way to (a) improve the thermal comfort and efficiency (more energy savings and lower greenhouse gas emissions) of buildings in the Mediterranean climate context, (b) further improve the technical and scientific knowledge, (c) increase the building value as it updates it toward current living standards and (d) contribute toward achieving greener buildings and cities.

Author Contributions: Conceptualization, S.B.-C. and D.A.; methodology S.B.-C., D.A., M.G.G. and A.M.R.; investigation, S.B.-C.; supervision, D.A., M.G.G. and A.M.R.; writing-original draft, S.B.-C.; writing-review and editing D.A., M.G.G. and A.M.R. All authors have read and agreed to the published version of the manuscript.

Funding: This study was supported by the Portuguese Foundation of Science and Technology (FCT), doctoral grant PD/BD/135171/2017, under the Eco Construction and Rehabilitation (Eco-CoRe) doctoral program.

Institutional Review Board Statement: Not applicable.

Informed Consent Statement: Not applicable.

Data Availability Statement: The data presented in this study are available on request from the corresponding author.

Conflicts of Interest: The authors declare no conflict of interest. 


\section{References}

1. Manzano-Agugliaro, F.; Montoya, F.G.; Sabio-Ortega, A.; García-Cruz, A. Review of bioclimatic architecture strategies for achieving thermal comfort. Renew. Sustain. Energy Rev. 2015, 49, 736-755.

2. Santamouris, M.; Pavlou, K.; Synnefa, A.; Niachou, K.; Kolokotsa, D. Recent progress on passive cooling techniques. Advanced technological developments to improve survivability levels in low-income households. Energy Build. 2007, 39, 859-866.

3. EU. Directive 2002/91/EC of the European parliment and the council of of 16 December 2002 on the energy performance of buildings. Off. J. Eur. Union 2002, 46, 65-71.

4. EU. Directive 2010/31/EU of the European Parliament and of the Council of 19 May 2010 on the energy performance of buildings (recast). Off. J. Eur. Union 2010, 53, 13-35.

5. EU. Directive of the European Parliament and of the Council on the energy performance of buildings (recast). Off. J. Eur. Union 2018, 61, 82-205.

6. Suárez, R.; Fernández-Agüera, J. Retrofitting of Energy Habitability in Social Housing: A Case Study in a Mediterranean Climate. Buildings 2011, 1, 4-15.

7. Asadi, E.; da Silva, M.G.; Antunes, C.H.; Dias, L.; Glicksman, L. Multi-objective optimization for building retrofit: A model using genetic algorithm and artificial neural network and an application. Energy Build. 2014, 81, 444-456.

8. Statistics Portugal-INE. Censos 2011 Resultados Definitivos. Available online: https://censos.ine.pt/ngt_server/attachfileu.jsp? look_parentBoui=148313382\&att_display=n\&att_download=y (accessed on 2 February 2021).

9. Diário da República. Decreto-Lei n.o 40/90, de 6 de Fevereiro-Aprovação do Regulamento das Características de Comportamento Térmico dos Edifcícios. D. Repúb. 1990, 40, 490-504.

10. Abreu, M.I.; Oliveira, R. O contexto atual da reabilitação energética do parque edificado em Portugal. Congr. Construção 2012, 1-12.

11. Magalhães, S.M.C.; Leal, V.M.S. Characterization of thermal performance and nominal heating gap of the residential building stock using the EPBD-derived databases: The case of Portugal mainland. Energy Build. 2014, 70, 167-179.

12. Stazi, F.; Bonfigli, C.; Tomassoni, E.; Di Perna, C.; Munafò, P. The effect of high thermal insulation on high thermal mass: Is the dynamic behaviour of traditional envelopes in Mediterranean climates still possible? Energy Build. 2015, 88, 367-383.

13. Alizadeh, M.; Sadrameli, S. Development of free cooling based ventilation technology for buildings: Thermal energy storage (TES) unit, performance enhancement techniques and design considerations-A review. Renew. Sustain. Energy Rev. 2016, 58, 619-645.

14. Ascione, F.; Bianco, N.; Rossi, F.D.; Turni, G.; Vanoli, G.P. Different methods for the modelling of thermal bridges into energy simulation programs: Comparisons of accuracy for flat heterogeneous roofs in Italian climates. Appl. Energy 2012, 97, 405-418.

15. Escandón, R.; Suárez, R.; Sendra, J.J.; Ascione, F.; Bianco, N.; Mauro, G.M. Predicting the Impact of Climate Change on Thermal Comfort in A Building Category: The Case of Linear-type Social Housing Stock in Southern Spain. Energies 2019, $12,2238$.

16. Filippi, M. Remarks on the green retrofitting of historic buildings in Italy. Energy Build. 2015, 95, 15-22.

17. Boeri, A.; Gabrielli, L.; Longo, D. Evaluation and Feasibility Study of Retrofitting Interventions on Social Housing in Italy. Procedia Eng. 2011, 21, 1161-1168.

18. Kottek, M.; Grieser, J.; Beck, C.; Rudolf, B.; Rubel, F. World Map of the Köppen-Geiger climate classification updated. Meteorol. Z. 2006, 15, 259-263.

19. Diário da Républica. Decreto-Lei n.o. 118/2013, de 20 de Agosto-Aprovação do Sistema de Certificação Energética dos Edifícios, do Regulamento de Desempenho Energético dos Edifícios de Habitação e do Regulamento de Desempenho Energético dos Edifícios de Comércio e Serviços. D. Repúb. 2013, 118, 4988-5005.

20. Garde, F.; Aelenei, D.; Aelenei, L.; Scognamiglio, A.; Ayoub, J. Solution Sets for Net-Zero Energy Buildings; John Wiley \& Sons: Hoboken, NJ, USA, 2017.

21. Stevanović, S. Optimization of passive solar design strategies: A review. Renew. Sustain. Energy Rev. 2013, 25, 177-196.

22. Souayfane, F.; Biwolé, P.H.; Fardoun, F. Thermal behavior of a translucent superinsulated latent heat energy storage wall in summertime. Appl. Energy 2018, 217, 390-408.

23. Ruiz, Á.; Salmerón, J.M.; Sánchez, F.; González, R.; Álvarez, S. A calculation model for Trombe walls and its use as a passive cooling technique. In Proceedings of the International Conference on Passiveand Low Energy Cooling for the Built Environment, Heliotopos Conferences, Santorini, Greece, 19-21 May 2005; pp. 365-369.

24. Rodrigues, A.M.; Santos, M.; Gomes, M.G.; Duarte, R. Impact of Natural Ventilation on the Thermal and Energy Performance of Buildings in a Mediterranean Climate. Buildings 2019, 9, 123.

25. Martínez-Molina, A.; Tort-Ausina, I.; Cho, S.; Vivancos, J.-L. Energy efficiency and thermal comfort in historic buildings: A review. Renew. Sustain. Energy Rev. 2016, 61, 70-85.

26. Cuce, E.; Riffat, S.B. A state-of-the-art review on innovative glazing technologies. Renew. Sustain. Energy Rev. 2015, 41, 695-714.

27. Kirimtat, A.; Koyunbaba, B.K.; Chatzikonstantinou, I.; Sariyildiz, S. Review of simulation modeling for shading devices in buildings. Renew. Sustain. Energy Rev. 2016, 53, 23-49.

28. Bellia, L.; Marino, C.; Minichiello, F.; Pedace, A. An Overview on Solar Shading Systems for Buildings. Energy Procedia 2014, 62, 309-317.

29. Saadatian, O.; Sopian, K.; Lim, C.; Asim, N.; Sulaiman, M. Trombe walls: A review of opportunities and challenges in research and development. Renew. Sustain. Energy Rev. 2012, 16, 6340-6351.

30. Hu, Z.; He, W.; Ji, J.; Zhang, S. A review on the application of Trombe wall system in buildings. Renew. Sustain. Energy Rev. 2017, 70, 976-987. 
31. Compagnon, R. Solar and daylight availability in the urban fabric. Energy Build. 2004, 36, 321-328.

32. Chatzipoulka, C.; Compagnon, R.; Kaempf, J.; Nikolopoulou, M. Sky view factor as predictor of solar availability on building façades. Sol. Energy 2018, 170, 1026-1038.

33. Stazi, F.; Mastrucci, A.; di Perna, C. The behaviour of solar walls in residential buildings with different insulation levels: An experimental and numerical study. Energy Build. 2012, 47, 217-229.

34. Koyunbaba, B.K.; Yilmaz, Z. The comparison of Trombe wall systems with single glass, double glass and PV panels. Renew. Energy 2012, 45, 111-118.

35. Brito, M.; Freitas, S.; Guimarães, S.; Catita, C.; Redweik, P. The importance of facades for the solar PV potential of a Mediterranean city using LiDAR data. Renew. Energy 2017, 111, 85-94.

36. European Comission. PV GIS. Available online: https://re.jrc.ec.europa.eu/pvg_tools/en/\#MR (accessed on 31 January 2021).

37. Mendonça, P. Habitar sob Uma Segunda Pele: Estratégias para a Redução do Impacto Ambiental de Construções Solares Passivas em Climas Temperados; Universidade do Minho: Braga, Portugal, 2005.

38. Tavares, M.C.P.; Gonçalves, H.J.P.; Bastos, J.N.T.D.F.C. The glazing area in residential buildings in temperate climate: The thermal-energetic performance of housing units in Lisbon. Energy Build. 2017, 140, 280-294.

39. Ministério da Economia e Inovação. Plano Nacional de Acção para a Eficiência Energética (PNAEE) 2015.2008.

40. Smith, N.; Isaacs, N.; Burgess, J.; Cox-Smith, I. Thermal performance of secondary glazing as a retrofit alternative for single-glazed windows. Energy Build. 2012, 54, 47-51.

41. Santos, H.; Valença, P.; Fernandes, E.O. UNESCO's Historic Centre of Porto: Rehabilitation and Sustainability. Energy Procedia 2017, 133, 86-94.

42. Rodrigues, F.; Parada, M.; Vicente, R.; Oliveira, R.; Alves, A.; Rodrigues, M.F. High Energy Efficiency Retrofits in Portugal. Energy Procedia 2015, 83, 187-196.

43. Bastos, J.; Batterman, S.A.; Freire, F. Life-cycle energy and greenhouse gas analysis of three building types in a residential area in Lisbon. Energy Build. 2014, 69, 344-353.

44. Rodrigues, C.; Freire, F. Integrated life-cycle assessment and thermal dynamic simulation of alternative scenarios for the roof retrofit of a house. Build. Environ. 2014, 81, 204-215.

45. Alves, S.; Sendra, J.J. Evaluating constructive and typological retrofits in solid masonry historic buildings. In Structural Studies, Repairs and Maintenance of Heritage Architecture XIV; Brebbia, C.A., Hernández, S., Eds.; WIT Press: Southampton, UK, 2015; pp. 381-391.

46. Rodrigues, C.; Freire, F. Building retrofit addressing occupancy: An integrated cost and environmental life-cycle analysis. Energy Build. 2017, 140, 388-398.

47. Eskander, M.M.; Sandoval-Reyes, M.; Silva, C.A.; Vieira, S.; Sousa, J.M. Assessment of energy efficiency measures using multi-objective optimization in Portuguese households. Sustain. Cities Soc. 2017, 35, 764-773.

48. Rodrigues, C.; Freire, F. Adaptive reuse of buildings: Eco-efficiency assessment of retrofit strategies for alternative uses of an historic building. J. Clean. Prod. 2017, 157, 94-105.

49. Monteiro, C.S.; Causone, F.; Cunha, S.; Pina, A.; Erba, S. Addressing the challenges of public housing retrofits. Energy Procedia 2017, 134, 442-451.

50. Carlos, J.S.; Corvacho, H. Retrofit Measures in Old Elementary School Buildings Towards Energy Efficiency. J. Civ. Eng. Manag. 2010, 16, 567-576.

51. Brás, A.; Rocha, A.; Faustino, P. Integrated approach for school buildings rehabilitation in a Portuguese city and analysis of suitable third party financing solutions in EU. J. Build. Eng. 2015, 3, 79-93.

52. Eicker, U.; Demir, E.; Gürlich, D. Strategies for cost efficient refurbishment and solar energy integration in European Case Study buildings. Energy Build. 2015, 102, 237-249.

53. Diário da Républica. Decreto-Lei n.o. 79/2006, de 4 de Abril—Aprovação do Regulamento dos Sistemas Energéticos de Climatização em Edifícios (RSECE). D. Repúb. 2006, 76, 2411-2415.

54. Panão, M.J.O. Revisiting cooling energy requirements of residential buildings in Portugal in light of climate change. Energy Build. 2014, 76, 354-362.

55. Sacht, H.; Bragança, L.; Almeida, M.; Nascimento, J.H.; Caram, R. Spectrophotometric Characterization of Simple Glazings for a Modular Façade. Energy Procedia 2016, 96, 965-972.

56. Moretti, E.; Belloni, E. Evaluation of energy, thermal, and daylighting performance of solar control films for a case study in moderate climate. Build. Environ. 2015, 94, 183-195.

57. Pereira, J.; Gomes, M.G.; Rodrigues, A.M.; Teixeira, H.; Almeida, M. Small-scale field study of window films' impact on daylight availability under clear sky conditions. J. Façade Des. Eng. 2020, 8, 73-84.

58. Pereira, J.; Gomes, M.G.; Rodrigues, A.M.; Almeida, M. Thermal, luminous and energy performance of solar control films in single-glazed windows: Use of energy performance criteria to support decision making. Energy Build. 2019, 198, 431-443.

59. Teixeira, H.; Gomes, M.G.; Rodrigues, A.M.; Pereira, J. Thermal and visual comfort, energy use and environmental performance of glazing systems with solar control films. Build. Environ. 2020, 168, 106474.

60. Causone, F.; Corgnati, S.P.; Filippi, M.; Olesen, B.W. Solar radiation and cooling load calculation for radiant systems: Definition and evaluation of the Direct Solar Load. Energy Build. 2010, 42, 305-314. 
61. Alcoforado, M.J.; Lopes, A.; Andrade, H.; Vasconcelos, J. Orientações Climáticas para o Ordenamento em Lisboa; Centro de Estudos Geográficos da Universidade de Lisboa (CEG UL): Lisbon, Portugal, 2005.

62. Ferreira, J.; Pinheiro, M.D. In search of better energy performance in the Portuguese buildings-The case of the Portuguese regulation. Energy Policy 2011, 39, 7666-7683.

63. Barbosa, R.; Vicente, R.; Santos, R. Climate change and thermal comfort in Southern Europe housing: A case study from Lisbon. Build. Environ. 2015, 92, 440-451.

64. Monzón-Chavarrías, M.; López-Mesa, B.; Resende, J.; Corvacho, H. The nZEB concept and its requirements for residential buildings renovation in Southern Europe: The case of multi-family buildings from 1961 to 1980 in Portugal and Spain. J. Build. Eng. 2021, 34, 101918.

65. Mingfang, T. Solar control for buildings. Build. Environ. 2002, 37, 659-664.

66. Gomes, M.G.; Santos, A.; Rodrigues, A.M. Solar and visible optical properties of glazing systems with venetian blinds: Numerical, experimental and blind control study. Build. Environ. 2014, 71, 47-59.

67. Gomes, M.D.G.; Rodrigues, A.M.; Bogas, J.A. Numerical and experimental study of the optical properties of venetian blinds. J. Build. Phys. 2012, 36, 7-34.

68. Sousa, J.; Silva, S.; Almeida, M. Energy Rehabilitation of Portuguese Residential Building Stock Through its Transformation into NZEB. In Seminário Reabilitação Energética de Edifícios; Almeida, M., Bragança, L., Silva, P., Silva, S., Mateus, R., Barbosa, J., Araújo, C., Eds.; Univ. of Minho: Minho, Portugal, 2012; pp. 41-48.

69. Ferreira, M.A.P.S.; De Almeida, M.G.; Rodrigues, A.C.R.A. Cost-optimal energy efficiency levels are the first step in achieving cost effective renovation in residential buildings with a nearly-zero energy target. Energy Build. 2016, 133, 724-737.

70. Capeluto, I.G.; Ochoa, C.E. Simulation-based method to determine climatic energy strategies of an adaptable building retrofit façade system. Energy 2014, 76, 375-384.

71. Palmero-Marrero, A.I.; Oliveira, A.C. Effect of louver shading devices on building energy requirements. Appl. Energy 2010, 87, 2040-2049.

72. Kim, G.; Lim, H.S.; Lim, T.S.; Schaefer, L.; Kim, J.T. Comparative advantage of an exterior shading device in thermal performance for residential buildings. Energy Build. 2012, 46, 105-111.

73. Tzempelikos, A.; Athienitis, A.K. The impact of shading design and control on building cooling and lighting demand. Sol. Energy 2007, 81, 369-382.

74. Aelenei, L.; Pereira, R.; Gonçalves, H.; Athienitis, A.K. Thermal Performance of a Hybrid BIPV-PCM: Modeling, Design and Experimental Investigation. Energy Procedia 2014, 48, 474-483.

75. Ulpiani, G.; Giuliani, D.; Romagnoli, A.; Di Perna, C. Experimental monitoring of a sunspace applied to a NZEB mock-up: Assessing and comparing the energy benefits of different configurations. Energy Build. 2017, 152, 194-215.

76. Oliveti, G.; Arcuri, N.; De Simone, M.; Bruno, R. Solar heat gains and operative temperature in attached sunspaces. Renew. Energy 2012, 39, 241-249.

77. Mihalakakou, G.K.; Ferrante, A. Energy conservation and potential of a sunspace: Sensitivity analysis. Energy Convers. Manag. 2000, 41, 1247-1264.

78. Patrício, A.; Gonçalves, H.; Saraiva, J. The use of sunspaces in Portugal. PLEA'98 1998, 98, 361.

79. Macieira, M.; Mendonça, P.; Guedes, J.M. Membrane Sunspace for Old Buildings Refurbishment: Environmental Impact, Economic and Building Technology's Comparison to Conventional Solutions. In Proceedings of the MATEC Web of Conferences, Lisbon, Portugal, 26-28 September 2018; Volume 278, p. 04002.

80. Aelenei, D.; Leal, H.D.A.; Aelenei, L. The Use of Attached-sunspaces in Retrofitting Design: The Case of Residential Buildings in Portugal. Energy Procedia 2014, 48, 1436-1441.

81. Özdenefe, M.; Atikol, U.; Rezaei, M. Trombe wall size-determination based on economic and thermal comfort viability. Sol. Energy 2018, 174, 359-372.

82. Hami, K.; Draoui, B.; Hami, O. The thermal performances of a solar wall. Energy 2012, 39, 11-16.

83. Zhang, T.; Tan, Y.; Yang, H.; Zhang, X. The application of air layers in building envelopes: A review. Appl. Energy 2016, $165,707-734$.

84. Sá, A.B.; Boaventura-Cunha, J.; Lanzinha, J.-C.; Paiva, A. An experimental analysis of the Trombe wall temperature fluctuations for high range climate conditions: Influence of ventilation openings and shading devices. Energy Build. 2017, 138, 546-558.

85. Briga-Sá, A.; Martins, A.; Boaventura-Cunha, J.; Lanzinha, J.C.; Paiva, A. Energy performance of Trombe walls: Adaptation of ISO 13790:2008(E) to the Portuguese reality. Energy Build. 2014, 74, 111-119.

86. Özbalta, T.; Kartal, S. Heat gain through Trombe wall using solar energy in a cold region of Turkey. Sci. Res. Essays 2010, 5, 2768-2778.

87. Dabaieh, M.; Elbably, A. Ventilated Trombe wall as a passive solar heating and cooling retrofitting approach; a low-tech design for off-grid settlements in semi-arid climates. Sol. Energy 2015, 122, 820-833.

88. Briga-Sá, A.; Boaventura-Cunha, J.; Lanzinha, J.-C.; Paiva, A. Experimental and analytical approach on the Trombe wall thermal performance parameters characterization. Energy Build. 2017, 150, 262-280.

89. Stazi, F.; Mastrucci, A.; di Perna, C. Trombe wall management in summer conditions: An experimental study. Sol. Energy 2012, $86,2839-2851$. 
90. Sacht, H.M.; Bragança, L.; Almeida, M.; Caram, R. Trombe wall thermal performance for a modular façade system in different portuguese climates: Lisbon, Porto, Lajes and Funchal. In Proceedings of the 12th Conference of International Building Performance Simulation Association, Sydney, Australia, 14-16 November 2011; pp. 1444-1450.

91. Stazi, F.; Mastrucci, A.; Munafò, P. Life cycle assessment approach for the optimization of sustainable building envelopes: An application on solar wall systems. Build. Environ. 2012, 58, 278-288.

92. Bellos, E.; Tzivanidis, C.; Zisopoulou, E.; Mitsopoulos, G.; Antonopoulos, K.A. An innovative Trombe wall as a passive heating system for a building in Athens-A comparison with the conventional Trombe wall and the insulated wall. Energy Build. 2016, $133,754-769$.

93. Soussi, M.; Balghouthi, M.; Guizani, A. Energy performance analysis of a solar-cooled building in Tunisia: Passive strategies impact and improvement techniques. Energy Build. 2013, 67, 374-386.

94. Aelenei, D.; Brito-Coimbra, S.; Gomes, M.G.; Rodrigues, A.M. Solar Bridge Retrofit System: An innovative solution to renovate structural thermal bridge areas. Energy Build. 2021, 236, 110784.

95. De Vasconcelos, A.B.; Pinheiro, M.D.; Manso, A.; Cabaço, A. EPBD cost-optimal methodology: Application to the thermal rehabilitation of the building envelope of a Portuguese residential reference building. Energy Build. 2016, 111, 12-25.

96. Ferreira, J.M.S.; Pinheiro, M.D.; De Brito, J. Refurbishment decision support tools: A review from a Portuguese user's perspective. Constr. Build. Mater. 2013, 49, 425-447.

97. Vares, S. Sustainable Refurbishment of Exterior Walls and Building Facades; VTT: Espoo, Finland, 2012.

98. Fernandes, D.; Santos, C.P.d.; Faria, P. A Realidade Da Reabilitação Em Portugal-Uma Abordagem Térmico-Energética. In Proceedings of the Congresso Internacional da Habitação no espaço Lusófuno, Lisboa, Portugal, 12-13 March 2013; pp. 1-13.

99. Galatioto, A.; Ciulla, G.; Ricciu, R. An overview of energy retrofit actions feasibility on Italian historical buildings. Energy 2017, $137,991-1000$ 